\title{
Marketing Preferences of Farmers in Banyuwangi Coffee Market
}

\author{
Yusmia Widiastuti ${ }^{1 *}$ \\ ${ }^{1}$ Department of Agrotechnology, University of 17 Agustus 1945 Banyuwangi, Banyuwangi, Indonesia \\ *Corresponding author. Email: yusmia@untag-banyuwangi.ac.id
}

\begin{abstract}
The plantation sector is a sector that plays a role in the country's foreign exchange earnings. One of the foreign exchange-producing plantation commodities is coffee. Around 61 percent of the total production is exported while the rest is consumed domestically and stored as carry stocks by traders and exporters, as a reserve in case of crop failure. To regulate something as big as the coffee trade, it is very important to have an institution that regulates the local market. The main objective of this study is to analyze the factors behind personalized transactions taking into account the case of the coffee market in Banyuwangi Regency. For this reason, the attributes of traders who are preferred by coffee selling farmers are identified. There are 5 independent variables studied, namely location, price, social relations, buyer trust, and dependence, and 1 dependent variable, namely coffee trade transactions. It can be concluded that of the five independent variables, only the dependent variable has no effect on coffee trade transactions. Simultaneously, these five variables have an effect on coffee trade transactions. With an adjudted R square of 0.273 or $27.3 \%$, so from this research there is still much that can be developed again.
\end{abstract}

Keywords: Coffee, Transaction, Marketing.

\section{INTRODUCTION}

The plantation sector is a sector that plays a role in the country's foreign exchange earnings. One of the foreign exchange-producing plantation commodities is coffee. In 2011, foreign exchange earnings from coffee commodities resulted in an export value of US\$ $1,085.89$ million or 10.1 percent of the export value of all agricultural commodities, or 0.5 percent of non-oil and gas exports or 0.4 percent of the total export value. The value of Indonesian coffee exports fluctuates. Fluctuating export values are more influenced by changes in coffee prices than changes in export volume [1].

Most of the coffee in Indonesia is cultivated by farmers with an average cultivated area of $0.5-1$ ha. In 2011 the coffee plantation area reached 1.3 million ha with a production of 709 thousand tons [2].

Around 61 percent of the total production is exported while the rest is consumed domestically and stored as carry stocks by traders and exporters, as a reserve in case of crop failure. The consequence of the large amount of coffee exported is Indonesia's dependence on the situation and conditions of the world coffee market.

To regulate something as big as the coffee trade, it is very important to have an institution that regulates the local market. Recent evidence suggests that agricultural commodity exchange in the region has so far failed to develop into a sustainable trading platform and even after its introduction, informal institutions still regulate local markets. Transactions in local markets remain private and are confined to narrow social circles linked by family lineages, acquaintances, and skinship. It is important to gain insight into the behavioral motives behind these personalized transactions and their implications for value chain performance.

In this case, they are expected to consider not only the price offered but also the characteristics of the trader in their decision. In addition, farmers sometimes cannot find buyers. In this case, they can also consider, in addition to price, the reliability of the merchant. Similarly, if some markets such as credit markets do not exist, farmers may still prefer to set up trades that provide loans, economic support and the like. For these and other reasons, farmers may prefer 
to establish long-term relationships with traders to lower these transaction costs.

Based on the problems that have been described, the hypothesis of this research is that:

a. H1 : Location affects coffee trade transactions

b. H2 : Price has an effect on coffee trade transactions

c. H3 : Social relations affect coffee trade transactions

d. H4 : Buyer's trust has an effect on coffee trade transactions

e. H5 : Dependence between farmers and traders has an effect on coffee trade transactions

f. H6 : Variables of location, price, social relations, buyer trust, and dependence together affect coffee trade transactions

The main objective of this study is to analyze the factors behind personalized transactions taking into account the case of the coffee market in Banyuwangi Regency. For this reason, the attributes of traders who are preferred by coffee selling farmers are identified. However, actual sales behavior may not fully reflect this preference as farmers may not have all the options in terms of merchant characteristics.

\section{THEORETICAL REVIEW}

The definition of location is explained by Von Thunen's theory, according to him that location is the dependent variable that affects the independent variables such as urban growth, economy, politics, and even community culture (lifestyle). This theory is based on his observations of the area where he lives which is agricultural land. The core of Von Thunen's theory is the theory of agricultural location which focuses on 2 main things about the spatial pattern of agriculture, namely the distance from the agricultural location to the market and the nature of agricultural products (durability, price, transport load). Von Thunen's Agricultural Location Theory model compares the relationship between production costs, market prices and transportation costs. Here is a schematic of the theory (Figure 1):

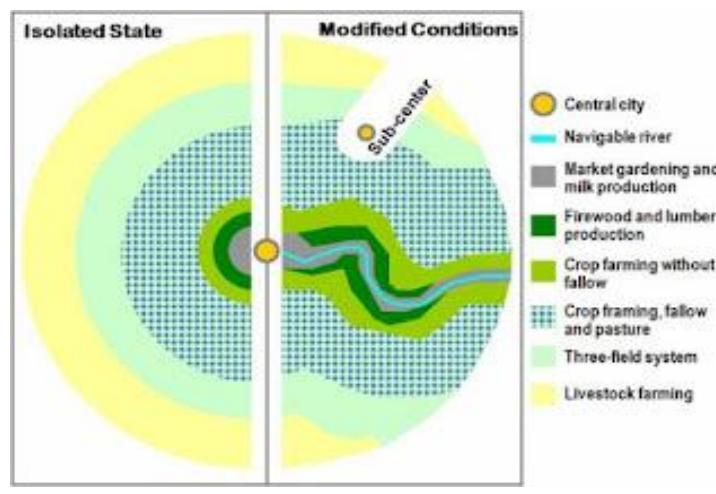

Figure 1. Von Thunen Agricultural Location Theory Model (source: [3])

The definition of price according to scientists is the amount of money charged for a product or service, or the amount of value that consumers exchange for the benefits of having or using the product or service [4]. The price of an item is the rate at which that item is exchanged for other goods. As we have seen, one of the main tasks of economics is to explain why goods have a price and why some goods are expensive and some are cheap [5].

The equilibrium price is the price at which neither consumers nor producers want to increase or decrease the quantity consumed and sold. Demand equals supply. If the price is below the equilibrium price, there is excess demand. Because demand will increase, and supply will decrease [6].

\section{METHODOLOGY}

\subsection{Research Design}

Uma Sekaran in [7] states that the research objective is directed to obtain information that can be used to solve problems. Based on the research objectives that have been set, the type of research used is explanatory research. Explanatory research aims to explain what will happen if certain variables are controlled or manipulated in a certain way. The approach used in this research is a quantitative approach. The process starts from theory, then it is lowered into research hypotheses accompanied by measurement and operational concepts, then empirical generalizations that rely on statistics, so that they can be concluded as research findings.

[8] argues that social interaction is a dynamic relationship that brings together people with people, groups with groups, and people with human groups. The form is not only cooperative, but also in the form of action, competition, dispute and the like. [9] more deeply states that social interaction is the process of 
one individual being able to auto-adjust to another individual, where he or she is influenced by another self. One individual can also adjust alloplasticly to another individual, where the other individual is the first to be influenced by him. Consumer trust is consumer knowledge about an object, its attributes, and benefits. Based on this concept, consumer knowledge is closely related to the discussion of attitudes because consumer knowledge is consumer trust. Consumer trust or consumer knowledge concerns the belief that a product has various attributes, and the benefits of these various attributes [10] According to [11] explained that consumer trust is "All knowledge possessed by consumers and all conclusions drawn by consumers made by consumers about the object, its attributes and benefits. Objects can be products, people, companies and everything in which a person has beliefs and attitudes. Attributes are characteristics or features that an object may or may not have. While the benefits are positive results given to consumers. Trust is generally seen as a fundamental element for a successful relationship. Without trust, a relationship will not last in the long term

\subsection{Method of Collecting Data}

Methods of collecting data were survey methods, observations, interviews, and questionnaires supported by secondary data obtained from related agencies.

Data collection through questionnaires was conducted by interview. Each variable is indicated by a statement and each statement in the questionnaire is given a scale using a Likert scale of $1-5$.

\subsection{Population and Sample}

The population here are coffee farmers and traders in Banyuwangi Regency. Due to the large number of population, samples were taken.

The sample is part of the number and characteristics possessed by the population [7].
According to [12], if the population is large or more than 100 , then $10-15 \%$ or $20-25 \%$ or more can be taken. To determine how many minimum samples needed can be done by using the formula method. The number of samples used were 85 farmers and coffee traders.

This study uses a purposive sampling technique, which is a sampling technique based on the researcher's considerations regarding which samples are the most appropriate, useful and considered to be representative of a population (representative).

\subsection{Data Analysis Method}

The data analysis method in this study used the regression analysis method. The regression analysis method used is multiple linear regression analysis which is transformed into multiple logarithms using natural logarithms, the equation form is as follows:

$$
Y^{\prime}=\beta_{0}+\beta_{1} X_{1}+\beta_{2} X_{2}+\beta_{3} X_{3}+\beta_{4} X_{4}+\beta_{5} X_{5}
$$

Where :

$$
\begin{array}{ll}
\mathrm{Y} & =\text { Coffee trading transaction } \\
\beta_{0} & =\text { Constanta } \\
\beta_{1-5} & =\text { Variable searched } \\
\mathrm{X}_{1} & =\text { Location } \\
\mathrm{X}_{2} & =\text { Price } \\
\mathrm{X}_{3} & =\text { Social Relations } \\
\mathrm{X}_{4} & =\text { Buyer's trust } \\
\mathrm{X}_{5} & =\text { Dependency }
\end{array}
$$

\begin{tabular}{|c|c|c|c|c|c|c|}
\hline \multirow{2}{*}{\multicolumn{2}{|c|}{ Model }} & \multicolumn{2}{|c|}{ Unstandardized Coefficients } & \multirow{2}{*}{$\begin{array}{c}\text { Standardized } \\
\text { Coefficients } \\
\text { Beta }\end{array}$} & \multirow[t]{2}{*}{$\mathrm{t}$} & \multirow[t]{2}{*}{ Sig. } \\
\hline & & $\mathrm{B}$ & Std. Error & & & \\
\hline 1 & (Constant) & 24,205 & 126,745 & & .595 & .352 \\
\hline & $\mathrm{X} 1$ & 5,912 & 3,876 & .656 & 8.160 & .000 \\
\hline & $\mathrm{X} 2$ & 7,152 & 5,923 & .828 & 9.353 & .000 \\
\hline & X3 & 6,533 & 4,873 & .746 & 7.243 & .000 \\
\hline & $\mathrm{X} 4$ & 2,184 &, 583 & .267 & 3.214 & .000 \\
\hline & $\mathrm{X} 5$ &,- 216 &, 014 & -.065 & -1.259 & .0354 \\
\hline
\end{tabular}

\section{RESULTS AND DISCUSSION}

\subsection{Results}

\subsubsection{Multiple Regression Analysis Results}

From the results of multiple regression analysis, obtained the equation:

$$
\begin{aligned}
Y^{\prime}=24,205+ & 5,912{ }_{1} X_{1}+7,152 X_{2}+6,533 X_{3} \\
& +2,184 X_{4}-0,216 X_{5}
\end{aligned}
$$

Table 1. Multiple Regression Analysis Test

Coefficients ${ }^{\mathrm{a}}$

a. Dependent Variable: Coffee trading transactions (Y) 
Based on the result, the following equation can be explained as follows:

1. A constant of 24,205 means that if the location, price, social relations, buyer trust, and dependence, then the coffee trade transaction is 24.205

2. The value of the location variable regression coefficient (X1) is 5.912, which means that if the location value is increased by 5.912 , there will be an increase in the value of the coffee trade transaction, but assuming the value of the other variables is constant.

3. The value of the variable regression coefficient (X2) the price of 7.152 means that if the price value is increased by 7.152 , there will be an increase in the value of the coffee trade transaction, but assuming the value of the other variables is constant.

4. The value of the variable regression coefficient (X3) of social relations is 6.533 which means that if the value of social relations is increased by 6.533 , there will be an increase in the value of coffee trade transactions, but with the assumption that the value of other variables is constant.

5. The value of the variable regression coefficient (X4) of buyer confidence is 2.184 , which means that if the value of buyer confidence is increased by 2.184 , there will be an increase in the value of the coffee trade transaction, but assuming the value of the other variables is constant.

6. The value of the regression coefficient of the dependency variable (X5) of 0.216 means that if the dependency value is increased by 0.216 , there will be a reduction in the value of the coffee trade transaction, but assuming the value of the other variables is constant.

7. Variables X1 to X5 simultaneously affect variable $\mathrm{Y}$ (coffee trade transactions)

\subsubsection{Hypothesis testing}

Hypothesis Testing (Ha), the basis for decision making:

1. If the value of Sig $<0.05$ or $\mathrm{t}$ count $>\mathrm{t}$ table, then there is an effect of variable $\mathrm{X}$ on variable $\mathrm{Y}$

2. If the value of Sig $>0.05$ or $t$ count $<\mathrm{t}$ table, then there is no effect of variable $\mathrm{X}$ on variable $\mathrm{Y}$

Based on Table 1, obtained the value of Sig. location $(\mathrm{X} 1)$ is $0.000<0.05$. Thus the t-test hypothesis for Ha (X1) has an effect. Thus the first hypothesis (Ha) can be proven or accepted, or there is an influence of the location variable on coffee trade transactions.
Based on Table 1, the t-test obtained the value of Sig. the price $(\mathrm{X} 2)$ is $0.000<0.05$. Thus the t-test hypothesis for Ha (X2) has an effect. Then the second hypothesis (Ha) can be proven or accepted, the variable that is very influential on coffee trade transactions is the price variable (X2).

Based on Table 1, obtained the value of Sig. social relations $(\mathrm{X} 3)$ is $0.000<0.05$. Thus the $\mathrm{t}$ test hypothesis for $\mathrm{Ha}$ (X3) has an effect. Thus the third hypothesis (Ha) can be proven or accepted, or there is an influence of social relations variables on coffee trade transactions

Based on Table 1, the t-test obtained the value of Sig. Buyer's confidence (X4) is $0.000<0.05$. Thus the t-test hypothesis for $\mathrm{Ha}(\mathrm{X} 4$,) has an effect. Then the fourth hypothesis $(\mathrm{Ha})$ can be proven or accepted, the most influential variable on coffee trade transactions is the buyer's trust variable (X4).

Based on Table 1, the t-test obtained the value of Sig. dependency (X5) is $0.0354<0.05$. Thus the t-test hypothesis for Ha (X5,) has an effect. Then the fifth hypothesis (Ha) can be proven or accepted, the variable that affects the coffee trade transaction is the dependent variable (X5).

Decision making basis:

1. If the value of Sig $<0.05$ or F count $>$ F table, then there is an effect of variable $\mathrm{X}$ simultaneously on variable $\mathrm{Y}$

2. If the value of $\mathrm{Sig}>0.05$ or F count $<\mathrm{F}$ table, then there is no effect of variable $\mathrm{X}$ simultaneously on variable $\mathrm{Y}$

Based on Table 2, the results of the $\mathrm{F}$ test of this study obtained an $\mathrm{F}$ value of 79.856 which is greater than $\mathrm{F}$ table 2.48 and significant value ( $\mathrm{P}$ value) of $0.000<0.05$, then the regression model can be used to test the effect of the independent variable on the dependent variable. Based on the table, it can be explained that the five variables, namely location, price, social relations, buyer trust, and dependence have a joint effect on the coffee trade transaction variables.

Table 2. F-Test Calculation

ANOVA ${ }^{\mathrm{a}}$

\begin{tabular}{|c|c|r|r|l|c|c|}
\hline \multicolumn{2}{|l|}{ Model } & $\begin{array}{l}\text { Sum of } \\
\text { Squares }\end{array}$ & df & $\begin{array}{l}\text { Mean } \\
\text { Square }\end{array}$ & F & Sig. \\
\hline 1 & Regression & 659,332 & 6 & 109,889 & 79,856 & $\begin{array}{c}, 000 \\
\text { b }\end{array}$ \\
\hline & Residual & 107,335 & 78 & 1,37609 & & \\
\hline \multicolumn{7}{|c|}{ Total } \\
a. Dependent Variable: Coffee trade transaction (Y)
\end{tabular}

b. Predictors: (Constant), Location, Price, Social Relations, Buyer Trust, Dependence 


\subsubsection{Coefficient of Determination Test}

Based on Table 3 below, the $\mathrm{R}$ value of 0.547 and the value of $\mathrm{R}$ square of 0.299 means that there is a strong influence between the variables of location, price, social relations, buyer trust, and dependence on the coffee trade transaction variable, the adjusted $\mathrm{R}$ square value of 0.273 or $27.3 \%$ of the variables of location, price, social relations, buyer trust, and dependence contributed to influencing the coffee trade transaction variables, while the remaining $72.7 \%$ was influenced by factors not examined in this study.

Table 3. Coefficient of Determination Test

\begin{tabular}{|l|l|l|l|l|}
\hline Model & R & $\begin{array}{l}\text { R } \\
\text { Square }\end{array}$ & $\begin{array}{l}\text { Adjusted } \\
\mathrm{R} \\
\text { Squarre }\end{array}$ & $\begin{array}{l}\text { Std. } \\
\text { Error of } \\
\text { Estimate }\end{array}$ \\
\hline 1 & \multicolumn{1}{|l|}{$.547^{\mathrm{a}}$} & .299 & .273 & 1.645 \\
\hline
\end{tabular}

\subsubsection{Price}

The results of the study prove that there is an influence between prices on coffee trade transactions. This is in line with the research conducted by [13] regarding the effect of price on purchasing decisions. From this research it can be concluded that this research contributes to the theory that the price has a positive effect on purchasing decisions is true. Price is also one of the factors that influence the increase in purchasing decisions.

Farmers seem to prefer to transact with traders who are open about prices. They seem committed to calculating short-term economic gains in order to build long-term relationships with traders.

\subsubsection{Location}

According to [14] "One of the keys to success/success is location, location starts with choosing a community". This decision is highly dependent on the potential for economic growth and stability, competition, business climate, and so on. Location selection is very decisive in business. A location that is located in the middle of a trade center or city center is the hope of all business owners. The location must be easy for customers to visit. The availability of various types of public transportation facilities for consumers so that consumers are easier to visit.

The selection of the right location will greatly influence the decision to transact in the coffee trade. Because location is also related to access (easy to pass and reach by means of transportation), visibility (can be seen clearly from the side of the road), traffic (many people passing by can provide a great opportunity for transactions), a large and safe parking space, expansion (the availability of a large enough place for business expansion in the future), the environment (the surrounding area that supports the business offered), and the location of competition

\subsubsection{Social Relations}

Granovetter said that social networks are the main capital in the economic sector [15] he emphasized that the placement of economic behavior in social relations can be explained through social networks that occur in economic life. social relations and the structure of social relations will result in trust and the occurrence of fraud by economic factors. Fraud of trust must be avoided, because an incident of trust due to bad failure therefore economic actors have to develop ways to avoid it.

Another important determinant of the factors that influence coffee trade transactions is social relations. Unlike in impersonal markets, economic relations in local markets are expected to be embedded in some kind of social relationship. The results show that farmers prefer traders who are members of their social group than groups who are not members.

\subsubsection{Buyer Trust}

Merchant trust (as perceived by farmers) was also found to be a significant determinant of choice. In markets characterized by information problems, farmers rely on their personal judgment and on their experience with traders' trust in providing market information, in measuring quality and quantity and in keeping promises and complying with contracts. Since objective quality measurement does not exist at the local market level, the honesty of traders in providing genuine quality assessments is an important behavioral attribute for farmers. A buyer is considered trustworthy if what he does and says can be trusted. Results shows that farmers prefer to deal with trustworthy traders.

\subsubsection{Dependency}

The dependence referred to here is the dependence of coffee farmers on certain coffee traders. This is usually highly correlated with other variables, such as price and social relations. However, in this study, the dependence of coffee farmers has no effect on coffee trade transactions. This condition can be explained because the existing coffee farmers usually already have links to many coffee traders. So if the coffee 
merchant who usually buys the coffee still has coffee in stock, even though there is still quite a lot of coffee production, then it is usually thrown to another coffee trader. In addition, there is a certain market segmentation created between coffee farmers and traders.

\section{CONCLUSION}

1. Price has a significant and positive effect on coffee trade transactions in Banyuwangi Regency. This is due to a commitment to calculating short-term economic benefits to build long-term relationships with traders

2. Location has a significant and positive effect on coffee trade transactions in Banyuwangi Regency. The location must be easy for customers to visit. The availability of various types of public transportation facilities for consumers so that consumers are easier to visit

3. Social relations have a significant and positive effect on coffee trade transactions in Banyuwangi Regency. Farmers prefer traders who are members of their social group rather than groups who are not members.

4. Buyer trust has a significant and positive effect on coffee trade transactions in Banyuwangi Regency. Farmers prefer to deal with trustworthy traders

5. Dependence has no significant and positive effect. Because farmers have many merchant links who can buy production from farmers

6. Simultaneously, the variables of price, location, social relations, buyer trust, and dependence have an effect on coffee trade transactions in Banyuwangi Regency

From this research, it is known that in coffee trading transactions, many things are involved. In this study only limited to 5 variables, namely location, price, social relations, buyer trust, and dependence. Coffee has indeed become the center of attention in Banyuwangi in recent years. Apart from the fact that many coffee plants in Banyuwangi Regency are cultivated in the form of smallholder agriculture, private plantations, and state plantations, there are also the proliferation of cafes that provide coffee for their customers. So it is necessary to examine in more depth about how the coffee market in Banyuwangi really is. Because this is a golden opportunity for the people of Banyuwangi Regency to be able to improve their economic welfare through coffee plants.

\section{ACKNOWLEDGMENTS}

The author would like to thank the coffee farmers and traders who are spread over 3 main points in Banyuwangi Regency, namely the north point covering the Kalipuro, Licin, and surrounding areas, the middle point covering the Songgon area, and the south point covering the Glenmore and Kalipuro areas and also to the Chancellor, Dean of the Faculty of Economics, University of 17 August 1945 Banyuwangi, colleagues who have provided input and suggestions for the perfection of this research, and all parties who have helped the realization of this research, hopefully this research can be useful for science

\section{REFERENCES}

[1] Asosiasi Kopi Spesial Indonesia, The 1st Indonesia Specialty Coffee Auction [Internet], Bali, 2010 October [cited 2019 Dec 5]. Available from: http://www.sca-indo.org

[2] Direktorat Jenderal Perkebunan. 2011. Luas areal dan produksi perkebunan seluruh Indonesia menurut provinsi dan status pengusahaan: komoditas kopi. [Internet], 2011 [cited 2021 Jan 4]. Available from: http://www.ditjenbun. go.

[3] J.P. Rodrigue, "Urban Transportation and Land Use", The Sage Handbook of Transport Studies, London: Sage, 2013.

[4] P. Kotler, and Amstrong, Prinsip-prinsip Pemasaran Edisi kedelapan. Erlangga, 2014.

[5] Alfred, Strategi Penetapan Harga. Andi, 2010.

[6] P. Rahardja, Teori Ekonomi Mikro edisi ketiga. Fakultas Ekonomi Universitas Indonesia, 2014.

[7] Sugiyono, Metode Penelitian Kualitatif. Bandung: Alfabeta, 2005.

[8] Basrowi, Pengantar Sosiologi. Bogor: Ghalia Indonesia, 2014.

[9] W.A. Gerungan, Psikologi Sosial. Bandung: Eresco, 2006.

[10] U. Sumarwan, Perilaku Konsumen: Teori dan Penerapannya dalam Pemasaran. Bogor: Ghalia Indonesia, 2011.

[11] J. C. Mowen, and M. Minor, Perilaku Konsumen. Jakarta : Erlangga, 2002.

[12] S. Arikunto, Prosedur Penelitian Suatu Pendekatan Praktik. Edisi Revisi. Jakarta: PT. Rineka Cipta, 2013. 
[13] D. Saputra, Pengaruh Harga dan Promosi Penjualan terhadap Keputusan Pembelian Konsumen pada Simcard XL di Kota Padang. Padang: Universitas Negeri Padang, 2005.

[14] P. Kotler, Manajemen Pemasaran Edisi 12 Jilid 2. Jakarta: Indeks, 2008

[15] Damsar, Sosiologi Ekonomi. Jakarta: PT. Raja Grafindo, 2002. 